\title{
The Relevance of Criminal Courts in the Global South
}

\author{
Pablo Leandro Ciocchini
}

Department of Sociology, Social Policy and Criminology, University of Liverpool in Singapore, 29B Tampines Avenue 1, \#03-02, Singapore 528694, Singapore; P.Ciocchini@liverpool.ac.uk; Tel.: +65-6592-8563

Received: 14 September 2017; Accepted: 6 December 2017; Published: 12 December 2017

\begin{abstract}
The literature on comparative law has a long and robust tradition, but studies comparing courts and judicial systems are scarce. Comparative studies in the Global South, following Shapiro's institutional approach, have aimed to measure the involvement of courts in politics by assessing the power of the judiciary in society, the level of judicial independence, and their role in the context of the judicialization of politics. The focus was on the high courts, including either Constitutional or Supreme Courts. Criminal courts have not received similar attention despite the influence of their everyday decisions on people's lives and their perception of the judicial system. This article argues that developing a comparative approach for criminal courts in the Global South is needed to help understand the role they play in the development of the rule of law and democratic life. This comparative study helps understand the impact of judicial reform programmes in the Global South. These reforms, inspired by a neoliberal paradigm, have focused on improving the efficiency of the courts. The reforms have promoted managerial techniques detrimental to the standards of due process. Any assessment of the impact of the reforms on the courts in the Global South should start by recognising the widely differing settings under which they operate. This context is characterised by serious economic constraints, such as a lack of material and human resources, and a democratic deficit legacy from the past authoritarian regimes, including widespread police abuse and corruption. Given this context, the role of the courts in ensuring due process and the legality of police procedures is crucial. The impact of the judicial reforms promoting managerial rationality in recent decades must be analysed. To examine the role courts are playing in criminal matters, two cases were explored where courts have undergone extensive judicial reforms, Argentina and the Philippines.
\end{abstract}

Keywords: criminal courts; Global South; Argentina; the Philippines; Duterte; criminal procedure; judicial reforms; comparative criminal justice; neoliberalism

\section{Introduction}

Courts have received attention due to the changes in governance caused by neoliberalism. The expansion and strengthening of democracy around the globe, and the emphasis on the rule of law, have increasingly imbued high courts with moral and political leadership. The phenomenon has been two-fold. Courts have gained leadership because of the political expectation that their decisions would have an important political impact, particularly in relation to minority rights. On the other hand, the shift in the leadership of courts has depoliticised some contentious political decisions, deactivating political debates and converting political struggles into legal conflicts. However, for criminal matters, the effect has been the opposite: the judicialisation of crime, as a result of the increasing crime rate in current societies, has resulted in the emergence of popular punitivism and the expansion of a managerial rationality in the criminal justice system.

Criminal courts, together with the other criminal justice institutions, are facing increasing societal demands to provide security, and must operate under intense scrutiny from politicians and the media. Scholars from the global north have argued that neoliberal reforms have emphasised the role of courts as government instruments to ensure social control, to the detriment of their adjudicative role (Simon 
2007; Garland 2001). ${ }^{1}$ For example, Bastard et al. (2016) showed how courts in France and Belgium have implemented new managerial mechanisms to achieve faster disposal times. A similar logic has driven misdemeanours courts in the U.S. to increase their disposal efficacy while hindering their adjudicative function (Kohler-Hausmann 2014). However, simply characterising the judicial reforms as managerial is a mistake. Most criminal procedures reforms in Western and Eastern Europe (except for the U.K.), Russia, Latin America, and some Asian countries have been driven by the implementation of the adversarial system. This trend in reforms, which started in the early 1980s, has been described as the Americanisation of justice (Mattei 2003). Adversarial reforms have been implemented in the name of due process, transparency, and accountability. Furthermore, the reforms have been argued to reduce courts' backlogs. Nevertheless, the examples of France and U.S. mentioned above show that to address the increasing societal anxiety about crime, managerial reforms have been prioritised over any other consideration.

Although some of the situation in the Global South resembles the situation described, significant differences also exist that exacerbate some of the most negative aspects of this managerial trend. The authoritarian past of the majority of countries in the Global South, and the consequently weak democratic institutions, have shaped the development of the courts, as well as of the other criminal justice institutions. Furthermore, courts have been operating under much higher levels of societal unrest, as a product of the extreme levels of social inequality and serious constraints on resources found in the economies of the Global South. Under these conditions, the reforms developed in the Global North have been implemented, forcing courts to adapt them to their local realities.

Therefore, the studies from the Global North cannot be used to understand the dynamics of courts in the Global South. As the individual analysis of each state is crucial to understanding the local political economy of the courts, the recognition of common debates and problems around the Global South calls for a comparative analysis of the impact of the judicial reforms. This comparative analysis should be able to identify similarities and differences in the political, economic, and cultural factors that have shaped the role of the criminal courts under neoliberalism. To illustrate the potential of a comparative framework, this article presents an exploratory study of the impact of reforms in the criminal courts of Argentina and the Philippines.

This article is organised as follows. The first section examines the impact of neoliberalism in the role of courts. Neoliberalism has promoted a judicialisation of politics that has empowered the courts. However, for criminal matters, the opposite has happened. The politicisation of crime has diminished the leadership of the courts, to the detriment of law enforcement agencies and politicians. Furthermore, this loss of leadership has been aggravated by reforms inspired by the neoliberal rationality focusing on reducing courts' backlogs. The introduction of managerial techniques and the simplification of criminal procedures by means of these reforms have curtailed the discretionary powers of the courts. The second section explores the potential of a comparative study of the courts in the Global South, describing the critical approach used to examine the reforms and the governmental narratives used as justification. The third section describes common factors that affect courts in the Global South. Courts

1 Although there is not unified definition of the global south (Carrington and Hogg 2017; Dados and Connell 2012; Santos 2016), a common agreement exists that the term helps to highlight the common experience of peripheral and semi-peripheral societies in the current globalised world, allowing us to refer to these societies without falling into terms heavily loaded with negative connotations such as "underdeveloped" or "developing" countries and "third world". Global South points to a section of the world that has suffered colonialism, and that it still is suffering from its enduring economic, political, cultural, and social legacy, without implying in any way that they are inferior to or falling behind the former colonial metropolis. The reference to the south is not strictly geographical, and the global adjective highlights the interconnection of southern countries, as a result of the colonial history and the current phenomenon of globalisation (Dados and Connell 2012). Importantly, the colonial violence exceeds the strictly economic and political realm by heavily influencing epistemological realm. As stated by Carrington and Hogg (2017), countries from the Global South " ... continue to occupy a subordinate position in the global organisation of social scientific knowledge". Thus, the reference to the global south invites us to engage in a south-south dialogue. This dialogue aims to help societies to learn from each other, in a non-hierarchical exchange of knowledge based on similar experiences. It is in this sense that we refer to the special situation in Southeast Asia and Latin America as regions of the Global South. 
in the Global South operate in societies that experience much higher crime rates than in the Global North. Criminal violence can be, at least partially, explained by the role these countries play in the global economy as providers of commodities and cheap labour. Moreover, courts in most countries of the Global South suffer the enduring effects of past authoritarian regimes-as do most governmental institutions-within their own organisation and in their relationships to others, such as the police. Such institutional weakness is exacerbated by chronic material and human resource constraints. Lastly, courts have been forced to implement reforms designed in societies of the Global North that do not suffer the same problems. The forth section analyses the cases of Argentina and the Philippines under this comparative framework, examining the impact that reforms have had in the role courts are playing in criminal matters in both countries. The article concludes by reflecting on the relevance of court leadership for democracies in the Global South to prioritise due process protection over managerial goals in judicial reform.

\section{Courts under Neoliberalism}

The role of courts is highly dependent on the political system in which they operate (Damaska 1986). Although Damaska (1986) has convincingly refuted the notion that the socio-economic structure determines the legal form of criminal procedures in a society, the political organisation of the state was found to deeply influence the functions that legal procedures, and therefore trial and criminal courts, are expected to fulfil. From a cultural approach, Garapon and Papadopoulos (2003) arrived at a similar argument: the political system shapes courts' functions and the structure of legal proceedings. However, these interpretations artificially split the economic and the political realm; rather, they should be understood as two dimensions of the same phenomenon, so neoliberalism influences the role of the state and the law, and indirectly influences the role of courts (Foucault 2008).

The rise and dominance of neoliberalism around the globe began in the mid-1970s in the Chile of Pinochet, and gained traction under the Thatcher and Reagan administrations in the U.K. and U.S., respectively. Neoliberalism finally spread worldwide after the collapse of the Soviet Union in the early 1990s, shaping not only the politics of the majority of countries, but also the common beliefs of their citizens (Harvey 2005). To understand its effects, we need to recognise that neoliberalism is more than the simple "... repudiation of Keynesian welfare state economics and the ascendance of the Chicago School of political economy" (Brown 2003). Neoliberalism is a political rationality that "... involves extending and disseminating market values to all institutions and social action" (Brown 2003).

Although not always evident, neoliberalism has promoted the introduction and the strengthening of the rule of law (Plant 2010). The rule of law is believed to provide legal predictability to social actions, by prescribing clear norms that order social interaction; but more importantly, it establishes clear boundaries for the political power of the state-a crucial requirement for the expansion of market economies. With its emphasis on the free market and predictability, neoliberalism set the role of the state under the rule of law as the guarantor of the framework under which the market operates (Harvey 2005). Thus, neoliberalism has a considerable impact on the distribution of political power among a state's institutions. By promoting restraints on the state's active intervention in the economy, emphasising the role of law in channelling and limiting political decisions, and relegating its role to an arbitrator between the market's actors, it has encouraged a shift in power from representative institutions to courts (Hirschl 2006). Under the concept of constitutional supremacy, high courts have been granted extended judicial review powers to protect constitutional rights, ultimately giving them power to shape a state's policies, and even decide on the allocation of economic resources, such as housing programmes (Hirschl 2006).

This phenomenon has been labelled as "judicialisation of politics", and has significantly changed the role courts play in contemporary societies (Santos 2002). One consequence of the judicialisation of politics has been the depoliticisation of social controversies, which have been translated into legal disputes and delegated to courts for their resolution. This legal translation has helped to de-mobilise political resistance and to increase the predictability of the outcomes of a conflict. Thus, we are 
witnessing a political rationality that has granted political and moral leadership to judges of high courts, and increasingly to judges of civil and commercial courts (Ciocchini and Khoury 2017). Furthermore, courts are now at the centre of political struggles, mobilised by politicians denouncing their opponents for corruption or lawsuits for defamation (Dezalay and Garth 2011).

Conversely, criminal judges are experiencing an opposite process. As crime has certainly been politicised in the last decades, the result has been inclusion in the political debate, instead of seclusion to the judicial realm. From the late 1970s onwards, crime has increasingly gained media attention, which has consistently fuelled the fear of crime, making it a central subject of political debate to the point where current political agendas are marked by "the crime problem" (Garland 2001). Criminal courts have always had to balance the tensions caused by punishing criminals, and have thus contributed to controlling crime while maintaining due process (Eisenstein et al. 1999). However, given the current politicisation of crime, courts are increasingly criticised not for the lawfulness or fairness of their decisions, but on their ability to provide security. Society, encouraged by the media and politicians, has increasingly blamed courts for their perceived leniency when handling criminal defendants (Garland 2001). Furthermore, the move away from the welfare state toward a neoliberal paradigm has produced unemployment, increased poverty, and exacerbated social inequality, all of which provide conditions conducive to an increase in crime (Reiner 2007). This has resulted in an exponential rise in the prison population in the central societies that have embraced a neoliberal system, such as the U.S., U.K., New Zealand, and Australia, where social welfare policies have been replaced by a punitive approach to poverty (Cavadino and Dignan 2006). Another consequence of this punitive policy has been an increase in the workload of the criminal justice system, including courts. This pressure has been conflated with the mantra of neoliberal policies for the reduction of the state's budget. These organisational pressures have facilitated a managerial influence that sought to increase the capacity of the courts to handle the higher workload through improving their efficiency and efficacy (Garland 2001). This managerial influence has also been evident in lower criminal courts. Kohler-Hausmann (2014) argued that lower criminal courts have moved away from the adjudicative process toward a managerial role where the regulation and sorting of defendants is the key focus. This is done through a series of legal and procedural tools that create records of the defendants, not necessarily related to the facts of the case, but focused on the number of encounters with law enforcement, which affect future procedures. Using this process, courts create profiles of low- and high-risk defendants over time, and treat them accordingly.

The pressure to hasten criminal court proceedings has impacted European jurisdictions, promoted through different types of procedural reforms aimed at simplifying procedures for minor crimes, and the introduction of bargaining mechanisms to avoid full trials (Eser 1996), to new organisational practices within public prosecutors and courts (Van De Kerchove 1998; Bastard et al. 2016). Common to all these reforms is that a non-adjudicative mechanism has been introduced to dispose cases to accelerate the procedures to match the speed of the media and politicians (Commaille 1998). However, if courts do not adjudicate, which is arguably the essential feature of courts, then their function and the extent to which they affect the democratic quality of current societies is in question. A risk of this trend is the complete capitulation of the courts, leaving the role of punishment to police and other state agencies, as illustrated by the introduction of non-court disposals in the U.K., such as penalty notices for disorder (Morgan 2009).

These demands for swifter responses have also affected the Global South, but due to the diverse material and cultural conditions, the result has taken a very different shape. To understand the type of managerialism and punitivism that has emerged in the Global South, we need to understand the political economy in which criminal justice, including its courts, operate. While analysing individual cases can help explain the uniqueness of each society, a comparative approach can help elucidate the role of geopolitics in shaping criminal courts in the Global South. A comparative approach helps to identify the role of Global North models, such as adversarialism, managerial tools, and-more broadly-neoliberalism, in the postcolonial violence that pervades the Global South. This article 
demonstrates the potential of this approach by comparing the development of criminal courts in two cases: Argentina and the Philippines.

\section{Comparative Studies of Courts}

High courts have gained political and moral leadership under neoliberalism, attracting the attention of comparative scholars. Comparative studies in Latin America and Asia (Helmke and Ríos-Figueroa 2011; Kapiszewski and Taylor 2008; Yeh and Chang 2015) have followed Shapiro (1981) institutional approach that focused analysis on the different functions of courts: conflict resolution, social control, and administrative tasks (Tate 1987). These studies have measured the involvement of courts in politics by assessing the power of the judiciary in society, the level of judicial independence, and the role of courts in the judicialisation of politics. In these studies, the focus was on how the social and political contexts shape the interactions of courts with other political actors (Yeh and Chang 2015). These studies have focused on the high courts, including both constitutional and supreme courts, and have left trial and criminal courts relatively unanalysed. Although decisions by the high courts may be politically relevant, criminal courts play a fundamental role in the strengthening and maintenance of the rule of law, and the protection of human rights (Popova 2012). Whereas prosecutors guide police investigations, courts exert an indirect control on the use of state violence by reviewing the legality of the behaviour of police and prosecutors. Everyday decisions in criminal courts, such as granting arrest warrants, bails, or a probation, have a huge impact on the lives of both victims and defendants, and they shape the perception of the judicial system of ordinary citizens. These minor but constant interventions in social life make criminal courts as relevant as, if not more than, higher courts in promoting and protecting the rule of law and the democratic political system. The role of criminal courts in promoting and protecting democracy is even more pronounced in the societies of the Global South that are still struggling with authoritarian legacies and facing extreme levels of poverty and social inequality.

This article contributes to the emerging comparative studies of criminal justice (Nelken 2011) by exploring the loss of leadership that criminal courts in the Global South are experiencing. Previous comparative studies of criminal procedures have explored the convergence of criminal procedures toward the adversarial model (Vogler 2005), and the reception of international fundamental rights and freedoms in the criminal process around the globe (Brants and Franken 2009). From a cultural approach, Garapon and Papadopoulos (2003) analysed the political function of criminal procedures, and particularly on the trial hearing, in the common-law jurisdictions, in contrast with the state-centred approach of French courts that prioritise substantive law. Popova (2012) used a comparative analysis of decisions in lower criminal courts on matters of electoral registration disputes and defamation lawsuits against media outlets to understand the political tensions between the judiciary and the government in Ukraine and Russia.

In this article, we built on these studies to explore how criminal courts have lost leadership under the politicisation of crime in the Global South. We argue that this has been a result of the combination of organisational constraints, as evidenced by their backlog, and the growing demand for security by the population, given an increasing fear of crime. The two cases explored show how the initial demand to strengthen due process to avoid police abuses was influenced by the past, and when facing the increasing demands for security, metamorphosed into a demand for faster procedures, negatively influencing proper control over police behaviour. In the dramatic case of the Philippines, courts were discredited for their delay, and are no longer leading the police "war" against drug-related offences.

A two-pronged analysis was used in this article to measure the role of courts in the context of the politicisation of crime in these jurisdictions. Firstly, a critical analysis was completed on the key reform programmes implemented in both jurisdictions. The aim of the analysis was to identify the rationale that drives these reforms, and the discourse used as justification. The analysis addresses the reforms with results based on the few available studies. Secondly, the role of the courts in the governmental narrative was explored, i.e., the narrative set by the statements of the government's officers and 
politicians' that, although not always consistent, an official discourse is established about the problem of crime and their role in it. The moral and political leadership of courts has been argued to be apparent when criminal policies are designed around the limits imposed by the interpretations of the law in their jurisprudence. This leadership can become direct when their interventions are covered by the press, or when the government publicly recognises their opinions. However, the government's policies may disregard the limits set by jurisprudence, the media may provide a largely negative coverage of courts' decisions, judges may not participate-or minimally participate-in public debates on criminal policies, and the government's narrative may neglect courts or openly criticise their interventions.

By comparing the similarities and differences in the impact the reforms have had in these two jurisdictions, particularly focusing on the leadership that courts have in criminal matters, this paper highlights the problematic consequences caused by the imposition of a managerial rationale.

\section{Violence and Criminal Courts in the Global South}

Carrington et al. (2015) argue that the thesis explaining the change toward punitive action in the Global North courts by attributing it to neoliberalism, cannot fully explain the developments in the Global South. Using examples from Latin American in the mid-2000s, governments of different states implemented social policies that could not be described as purely neoliberal; however, incarceration rates grew more slowly than in past decades. Thus, they claimed that the link between "governmental experiences and penalty is more complex" (Carrington et al. 2015) and requires a proper exploration of the conditions in the Global South. Two main historical factors have shaped the crime field in the Global South: the enduring legacies of past authoritarian regimes, and the brutal socio-economic inequality that marginalises a significant sector of the population. These two factors are responsible for other factors affecting the criminal justice system, and thus the criminal courts, including the high crime rate in these societies and the chronic inefficiency of the state's bureaucracies. These four factors should be better explored to understand the operation of criminal courts in the Global South.

\subsection{The Authoritarian Past}

Most countries in the Global South have experienced different types of authoritarian regimes between the 1960s and 1980s. By the beginning of 1990s, after the fall of the Soviet Union, although the regimes had transitioned toward democracy, the authoritarian regimes had left long-standing legacies that still influence the states' institutions today. Thus, democratic institutions are not as consolidated as in the Global North, with frequent institutional disruptions, and strong executive powers that compensate for the institutional weakness. For the criminal courts, this legacy has triggered reforms all over the Global South to improve their accountability and transparency, and to introduce more democratic practices, such as public oral trials. A consequence of the authoritarian legacy is that the police operated autonomously without proper oversight by civil society, which is serious considering the widespread claims of police brutality and corruption in countries in the Global South (Hinton and Newburn 2008; Auyero and Sobering 2017).

\subsection{The Political Economy}

Understanding the role of societies in the Global South is crucial when exploring the significantly higher crime rates and the organisational deficiencies of the courts. Countries from the Global South can be categorised into two equally problematic roles. A large group of countries, including most Latin American and African countries, continue the colonial legacy by providing the primary materials to fuel foreign industrialisation. Under the neoliberal global hegemony that opened their markets to foreign direct investment, this legacy has been reinforced, giving rise to "predatory extractivism" (Hollender 2015). The other group of countries from the Global South have focused their economy on the provision of a cheap labour force. Workers in these countries are exploited under labour regimes whose laws have failed to protect them, to the point that Whyte (2009), using Agamben's framework, argued that these workers become naked labour in mass labour camps. These violent economic 
conditions have produced and reinforced social inequalities and structural poverty, exacerbated by neoliberal policies, such as the privatisation of public services, placing large sections of the population in precarious situations. Two immediate consequences of this economic situation occur in the criminal justice system. Firstly, the extreme inequality caused by this economic arrangement has caused crime rates to rise (Cavadino and Dignan 2006; Fajnzylber et al. 2002). Secondly, the extractive industry requires significant capital investment that originates from companies in the Global North. Based on the perceived political risk of their operations, these companies have historically paid lower taxes than what they would have for a similar economic activity in the Global North (Stürmer 2010; Svampa 2013). Similarly, industries that rely on intensive labour will relocate their factories if governments increase taxes in a way that affects the low-cost labour equation that originally incentivised the investment. This has resulted in the historic underfunding of the state. Thus, courts in the Global South often suffer from understaffing and lack basic resources, including proper courtrooms, computers, and even pens and paper (Widner 2000).

\subsection{The Structural Violence}

The economic regimes in the Global South damage the environment and marginalise large sections of the population (Svampa 2013). This economic violence is exacerbated by the expansion of mass consumption that reinforces class distinctions and relative poverty (Young 2001), resulting in an exponential increase in crime (Wacquant 2009; Patalinghug 2011; Müller 2012).

The type and level of structural, organised, and interpersonal violence under which criminal courts operate in the Global South is different from their counterparts in the Global North (Carrington et al. 2015). Comaroff and Comaroff (2014) explained the economic and political changes suffered in the Global South " ... have had unintended, highly destabilizing effects on the fragile political and economic arrangements—on the ecologies of patronage, redistribution, and survival — that developed in many nation-states across the Global South with the end of the high age of colonialism." Fuelled by the mass media, this violence has triggered both a widespread fear of crime and its politicisation (Swanson 2013). Although the phenomenon is similar in the Global North, the level of criminal violence, combined with the level of police violence and the bureaucratic limitations of the courts, has created a different tone in the political debate.

\subsection{Bureaucratic Inefficiency}

Lastly, the inefficacy and inefficiency of the state's bureaucracies in the Global South must be acknowledged. This inefficiency has been explained as a result of some of the factors mentioned before: economic constraints, a general lack of material and human resources, endemic corruption that affects daily operations and hampers any meaningful reforms of the state's organisation, and a lack of transparency and accountability that fosters corruption and other types of abuses (Hyden et al. 2003). This bureaucratic inefficiency has enabled neoliberal reforms promoted and sponsored by international finance, such as the. World Bank and the International Monetary Fund (IMF), and aid agencies from central societies such as the U.S. Agency for International Development (USAID). Reforms in the criminal courts were part of this larger programme of state reforms. These reforms were aimed at democratising the state, to securing due process in the courts by adopting adversarial systems, and improving the efficiency of the courts. As seen in the case analyses of Argentina and the Philippines, after the first wave of reforms, managerial pressures were prioritised to the detriment of due process.

These factors interact to create a difficult and complex situation for criminal courts. Facing organisational strains, a higher workload resulting from punitive policies, and pressures from the population, as well as being fuelled by politicians and the media, the courts have lost leadership in an attempt to provide security.

The analysis of Argentina and the Philippines explored how criminal courts lost their capacity to control the police and public prosecutors. Argentina is a perfect example of what has occurred in Latin America in recent decades. Reforms that were meant to improve due process ultimately imposed 
a bargained justice system and simplified procedures that has resulted in convictions mainly based on police reports, without a proper cross-examination of the evidence. The Philippines has become notorious for the punitive policies implemented under President Duterte, particularly the thousands of extrajudicial killings rationalised by his "war on drugs". These two cases, which are analysed in the following sections, illustrate the loss of leadership of courts: one by managerial pressures, the other by the uncontrolled expansion of police violence.

\section{Implementing Adversarialism to Managerialism in Argentina}

In Argentina, the loss of political and moral leadership of the criminal judges has been caused by the combination of the political and media public discourse on crime, and legal reforms that were originally aimed at improving the due process, but which later shifted their focus to improving the efficiency of the courts.

Argentina is a typical example of the transformations that criminal procedures have undergone in Latin America. Argentina, as has been the case with most Latin American countries, started to reform its criminal procedures after the transition to democracy in the early 1980s. Vogler (2005) defined these reforms toward an adversarial system as a "due process revolution", caused by the American leadership. The hundred-year-old criminal procedure codes in force in the region were labelled "inquisitorial" and were identified with an authoritarian culture. They were replaced with adversarial and accusatorial legal procedures meant to be more transparent and efficient (Binder 1997; Duce and Pérez Perdomo 2001; Maier 1993). The major concern about these early reforms was the replacement of highly regulated and formalistic written procedures with less formalised procedures where the verdict and other relevant decisions were decided in public oral hearings, including a pre-trial, trial, and appeal hearings. This was meant to provide accountability and increase efficiency, as scholars and politicians agreed that written procedures had promoted a highly inefficient bureaucracy that was blamed for the chronic backlog in courts (Duce 2009). This was not a minor concern; in Latin America, the widespread use of pre-trial detention combined with this serious backlog resulted in prison overcrowding due to defendants awaiting trial (Carranza 1996).

This first wave of reforms started with a bill for reforming the Criminal Procedure Code (CPC) in Argentina's federal jurisdiction. The bill was heavily influenced by the German Criminal Procedure Code and was meant to democratise and improve the efficiency of the criminal courts (Langer 2007). Although the bill was never passed, it was influential in the region. A network of legal scholars in Latin America promoted reforms based on the bill, with financial support from international financial organisations including the World Bank and the Inter-American Development Bank, and aid agencies such as USAID, the German Society for Technical Cooperation, the Konrad Adenauer Foundation, and the United Nations Development Programme, among others. In 1992, the province of Córdoba, Argentina, and Guatemala were the first jurisdictions in the region to adopt CPCs based on the initial bill. Two decades later, more than 14 Latin American countries had reformed their CPCs.

Politicians and reformers argued that backlogs were the result of the old inquisitorial system and that the introduction of public trials would hasten procedures, and eradicate the backlog (Ciocchini 2014). However, as found in the traditional adversarial jurisdictions such as the U.S. or England, the new procedural systems included other tools to reduce court backlog. Local versions of plea bargaining and different diversion mechanisms were introduced to reduce the caseload of the criminal courts. These mechanisms supplied public prosecutors, who had already gained power in the new adversarial system, with discretionary powers to the detriment of judges. Public prosecutors used to have a rather passive role in the inquisitorial system; but with the new adversarial procedures, in addition to actively leading the prosecution process, they were responsible for conducting the investigation, which used to be part of the judge's remit.

Despite these legal changes, replacing the inquisitorial system with an adversarial system did not achieve the desired outcome. Oral hearings were largely avoided by those in the judicial system, with written decisions being favoured, relying on written case files. The court backlog was not significantly 
reduced, and public prosecutors, instead of exerting a tighter control on police, delegated the direction of the investigation to them (Hazán and Riego 2007). The court's backlog and the lack of control over the police were exacerbated by the widespread fear of crime that was triggered by the increase in violent crimes, and was further fuelled by the mass media during the 1990s (Kessler 2016). The fear of crime marked the political agenda of Latin American governments and further weakened the already limited legitimacy of the police and criminal courts.

Given these failures, a second wave of reforms occurred at the beginning of the 21st century. These reforms more explicitly focused on reducing the court backlog, and were promoted by the Centre for Judicial Studies of America (CEJA), a Chile-based international organisation belonging to the Organisation of American States (OAS). CEJA's approach centred on organisational changes (REDEX 2010). Recognising the failure of the first wave of reforms, this second wave focused on changing judicial practices (Binder 2002; Duce et al. 2002). Although they have faced obstacles to implementation ranging from the resistance of members of the judiciary and unsteady support from local governments to the lack of material resources such as computers or courtroom space, the reforms are considered to have been successful in terms of reducing the disposition time for cases in which the defendant was caught in the act (Pasará 2015). Expedited trials were introduced for these cases with early pre-trial hearings with incentive plea bargaining agreements.

However, these reforms have aggravated the already problematic inability of prosecutors and courts to "control" police work. Public prosecutors who oversee the police during investigations, and at pre-trial and trial courts, are expected to control the legality of the procedures. However, in practice, the majority of cases are based on the evidence collected by the police at the moment of arrest, following a poor or non-existent investigation (Fondevila et al. 2016).

Furthermore, expedited trials to reduce backlog problems for cases in which the defendant was caught red-handed have resulted in courts focusing their resources on these cases to the detriment of more complex cases. These cases are typically settled before the trial based on police reports and without a proper cross-examination of the evidence. In the few complex cases that proceed to trial, defendants must wait years in detention prior to attempting to prove their innocence.

The contradictions between the changes in criminal procedures following the political programme to democratise the state, and the increasing demands from society and politicians fuelled by the mass media for a punitive response to reduce crime rates (Gutierrez 2017), has manifested in criminal courts as a tension between progressive and conservative judges. The tension has developed into a criticism of the function of the criminal justice system in a given society. In Argentina, judges and judicial actors are generally labelled by the media and politicians as "garantistas", i.e., those whose main role is to guarantee constitutional rights (Werner 2017). There is a tension within the judicial institution between the liberal garantistas judges and more conservative judges and prosecutors openly support tough-on-crime policies. These conservative judges explicitly argue that law should be interpreted to enable a more punitive outcome, despite the original intention of the legislators.

Judges used to direct investigations, and were therefore able to impose their own criteria upon the police. However, their role has been reduced to granting or denying the prosecutor's request. Combined with the intense pressure judges receive from politicians and the media, they have lost their de facto autonomy. In practice, their role has been redefined to the technical control of the legality of the punitive decisions made by police. This loss of leadership could be interpreted as the result of a shift from penal welfarism toward popular punitivism with a distrust of penal experts (Garland 2001; Pratt 2007). A more emotional punitive discourse that considers legal protections as obstacles to justice was the focus. Although this is a trend that has been widely explored in central societies such as the U.S. and the U.K. (Garland 2001), the trend has been expressed differently in semi-peripheral societies, such as Argentina. Although the fear of crime is pervasive in both cases, in the former the actual crime rate has been reduced (Levitt 2004), whereas in the latter, it has dramatically increased (Carrington et al. 2015). Related to this phenomenon is the fact that the courts and the police in the U.S. and U.K enjoy high levels of confidence (Indermaur and Roberts 2009), whereas the opposite is 
true in Argentina (Oyanedel 2016). Nevertheless, a disempowering of judges is common in all of these cases; in the U.S., mandatory minimum sentences and mandatory guidelines have removed power from judges (Simon 2007), whereas in Argentina, this has been achieved through legislative changes that have increased minimum sentences and restricted parole, among other measures.

Two other significant elements have promoted the reduction of judges' political and moral leadership: the fear of becoming a media target or political defamation due to judicial leniency (Kostenwein 2015), and the imposition of a managerial rationale with the goal of quickly closing cases (Ciocchini 2014). Caution is required here, as stated by Kostenwein (2015), because press reports on the criminal justice system are not homogenous; in some cases, they support a more critical approach to punishment, and in other cases, judges use the press as a pretext to justify their own ideological decisions. Ciocchini (2014) asserted that judges have managed to partially neutralise some managerial pressures. However, the combination of these two aspects, and the legislative changes mentioned above, have increasingly forced judges to take a punitive stance. To address the severe lack of public confidence, criminal courts have been subjected to a series of performance improvement reforms. This process assumes that the legitimacy crisis is due to the courts' inefficiency. Furthermore, greater efficiency is assumed to more effectively punish crime, creating the feeling of safety for the public while resulting in faster and fairer cases for defendants.

Although the managerial rationale has not yet measured the performance of judges in terms of sentencing, it has forced them to focus their efforts on street crimes, and to promote plea-bargaining and other mechanisms that result in a lack of cross-examination of the evidence gathered by the police. Under managerialism, adversarialism — the confrontation between the prosecutor and the defendant before a judge-is slowly being dissolved and replaced by an administrative perspective that focuses on the standardisation of case disposal and the maximisation of system efficiency. A paradoxical result of the relevance of the crime phenomena in semi-peripheral societies has been the loss of leadership of criminal judges. Managerialism and penal punitiveness have created technicians of repression out of the judges in Argentina.

\section{When Courts Are Neglected}

A more extreme case of loss of moral and political leadership by judges has been demonstrated in the Philippines. In this case, the courts have been completely removed from the debate about and implementation of crime policies, particularly in the so-called war on drugs. As a result, state violence has been unleashed without legal control.

Firstly, understanding the role of the authoritarian past in shaping the role of courts in the Philippines is important. The Philippines were ruled under an authoritarian regime by Ferdinand Marcos until 1986. With the end of his regime, the Philippines transitioned to a democratic era. However, the democracy of the Philippines still suffers from weak institutions, and power is still concentrated in a strong presidency. Due to institutional weakness and institutionalised corruption, the ability of the Philippines state to implement policies is rather limited (Timberman 2016). This inability of the state, together with the objective of avoiding relapsing into an authoritarian regime, has enabled the empowerment of the court and the consequent judicialisation of politics (Tate 1994). Several factors could have helped foster the judicialisation of politics in the Philippines: a liberal democracy, separation of powers, a politics of rights, interest groups and opposition use of the courts, and frequently ineffective majoritarian institutions with limited public respect. The judicialisation of politics was further encouraged by the newly enacted Constitution in 1987, which assigned to the judiciary new and expanded powers and responsibilities, and introduced a Bill of Rights (Tate 1994).

However, the level of judicialisation of politics achieved after three decades of democracy is disputed. Dressel (2012) qualified the Philippines judiciary as activist, Ciencia Jr. (2012) highlighted how the process politicised the judiciary, and Gatmaytan (2012), although agreeing with that diagnosis, added that such politicisation damaged the judiciary leadership. Describing a series of decisions of the Supreme Court that were highly criticised by scholars, politicians, and the media, Gatmaytan (2012) 
argued that the judiciary transition to a level of politicisation has hampered its legitimacy. He explains that the empowerment of the Supreme Court threatened the leadership of the executive and legislative power, so an attempt was made to simultaneously co-opt the members of the Court and publicly discredit them. Gatmaytan's findings are aligned with those of Haynie, who argued that the tensions between the judiciary and the other public powers raised the public awareness of the political nature of the court, undermining the legitimacy of the institution (Haynie 1998; cited in Gatmaytan 2012). This loss of leadership is illustrated by the public remarks made by the former Chief Justice of the Supreme Court of the Philippines, given the attempt made by the executive to control the budget of the judiciary. The Chief Justice stated that "Never before has the entire judiciary, even in the days of martial law, been subjected to so much disrespect and lack of civility from sectors we sincerely consider to be our partners in nation-building." (Fonbuena 2011 cited in Gatmaytan 2012).

Perhaps even more influential in the loss of moral and political leadership of the courts than open involvement in political cases has been the bureaucratic inefficiency that has affected the entire judicial system, which is apparent in the brutal backlog. Philippine courts have long been suffering from an endemic backlog, hampering their ability to offer timely solutions (Tadiar 1980). This has been recognised by the current Chief Justice of the Supreme Court of the Philippines, when she publicly stated that courts are currently characterised by delay (Torres-Tupas 2014). This level of inefficiency led Phelim Kine, a deputy director of the Asia Division at Human Rights Watch, to declare that "The fact is that the judicial system, the court system, is broken in the Philippines," (Taub 2016).

This historically severe court backlog has enabled a series of reforms in recent decades, sponsored by international donors from the Global North. According to the Philippine Supreme Court, at least 40 technical studies on court administration have been completed since the 1990s to support programmes such as the Technical Assistance of the Philippine Judiciary on Justice and Development (1996-1999), the Blueprint of Action for the Judiciary (1999), the Action Program for Judicial Reform (2001-2010), the Judicial Reform Support Project (2001-2012), and the Judiciary and Legal Profession Development Plan (JLPDP). The most recent reform in Philippine courts has been heavily focused on improving courts' disposition efficiency using mechanisms such as the implementation of continuous trials. This programme provides guidelines for conducting cases, regulating the motions that parties can raise by prohibiting some and shortening the period for presenting others. The programme also regulates courts' agendas by requiring trials to be conducted from Monday to Thursday, leaving Fridays free for addressing motions, arraignment, and pre-trial conferences (Punay 2017a). This programme has been promoted by the American Bar Association.

A common feature of these programmes has been the merging of accountability and the protection of human rights with managerial goals. For example, a recently implemented programme, Governance in Justice (GoJust), which was developed and funded by the European Union and the Spanish government, aims to strengthen the ability of institutions to promote accountability and oppose impunity for major human rights violations. However, the programme states these goals are dependent on developing the coordination and streamlining of the case management system within criminal justice agencies, decongesting courts and prosecution offices, and improving the administrative and financial management systems (Punay 2017b).

The limited success of these reforms, acknowledged by the very organisations sponsoring the reforms and the Philippine government itself, raises concerns about whether the reforms based on the experience of central societies are suitable for the conditions of a semi-peripheral society, such as that in the Philippines. Furthermore, this emphasis on efficiency highlights the impacts these programmes have had on courts' adjudication function. Adjudication is essential to courts, providing critical oversight of the evidence in a given case and, indirectly, of the legality of police behaviour. This is particularly relevant in the Philippines because of the multiple reported cases of police corruption and abuse.

Courts' inability to respond as expected to the crime wave has enabled the implementation of policies such as those implemented by the Duterte administration. These policies have empowered 
police forces to operate without the accountability and transparency required by a democratic system that operates under the rule of law, thus prioritising crime control over due process. Duterte's policies have resulted in the extrajudicial killing (EJK) of more than 7000 individuals by death squads.

Under his presidency, the loss of leadership of the judiciary has been more evident. Despite constant growth in the last decade in the Philippines, poverty and inequality have remained alarmingly high. Duterte offered the population an alternative to the ruling elites (Timberman 2016). The judiciary decisions and scandals highlighted their deep association with that very same political elite (Ciencia Jr. 2012). Duterte has fuelled this narrative by accusing judges of corruption and collusion with drug dealers (Corrales 2016). Furthermore, the Chief Justice of the Philippine Supreme Court reacted to that public accusation with an open letter to the President in which she warned him that it was the function of the high court to penalise erring judges and asked him, in the sake of preserving public confidence in the judiciary, to avoid public allegations of that kind (Ramos 2017). Duterte's response was to threaten the Chief Justice, ordering her not to " . . create a crisis because I will order everybody in the executive department not to honour you." This harsh treatment of the judiciary influenced the lack of leadership and support from the government.

Duterte has approached his war on drugs by replicating the tactics he used in Davao City when he was mayor: to unleash police violence against not only drug dealers, but also consumers (Rauhala 2016). Duterte has used the language of war against drugs and criminality to exploit the fears and anxieties of the population. These citizens hope that a radical departure from the politics of elitism will improve their living conditions (Curato 2016). Curato (2016) stated:

“Duterte's predecessor, Benigno S. Aquino, prioritised programmes that fight crimes in a deliberate, programmatic and sustained manner to control crime... [while Duterte has promised] to overcome the corrupt bureaucracy in the just system and deliver peace and order in a swift and decisive manner." (p. 96)

The courts were completely removed from the state's strategy to address drug-related crimes. This disregard for the judiciary led Duterte to openly threaten the Supreme Court with declaring martial law if it interfered with him (Barrera 2017). Furthermore, he has openly supported the policy of shooting suspects, and even confessed he used to shoot suspects himself when he was Mayor of Davao (Holmes 2016). Moreover, when addressing the report of the Human Rights Watch that accused Duterte of crimes against humanity, he stated: "When you kill criminals, that is not a crime against humanity. The criminals have no humanity. God damn it," (Romero 2017). Although Duterte's remarks do not necessarily translate into concrete policies, they have an important symbolic value. They set the government's narrative on crime presenting constitutional rights and courts as obstacles to punish criminals and provide safety. The result of his brutal penal populism policy has been the killing of more than 7000 people since Duterte took office (Human Rights Watch 2017).

Notably, extrajudicial killings did not start with Duterte's presidency. They are a legacy of the authoritarian regime of Marcos and were already common in previous administrations (Medina 2017). However, under Duterte, they have been normalised as a strategy used to fight drug trafficking. Kreuzer (2016) argued that this adaptive strategy was used by the Philippines state to address the problem of denying their complicity in vigilantism; instead, vigilante action has been designated as the legal application of force by state security agents. This understanding of the state's strategy explains the notorious absence of any reference to judges or courts in the political debate on the war on drugs, besides accusing them of complicity with drug traffickers.

The courts, however, are not only relegated in relation to the extrajudicial killings, but have been restricted regarding Duterte's strategy for fighting drug-related crime, which is purely focused on increasing police power. His flagship anti-crime police programme, called Project Double Barrel, consists of a two-pronged approach: Project Tokhang and Project High Value Target (HVT) (Calisco et al. 2017). The project involves “... the conduct of house to house visitations of alleged illegal drug users and pushers to convince them to voluntarily surrender and/or stop using illegal 
drugs". Project HVT is being conducted by a special police force, and aims to dismantle the large-scale smuggling, manufacturing, and trafficking of illegal drugs. Related to this focus on police, the government efforts to address police corruption should be addressed. To achieve this goal, a policy of "internal cleaning" that has included the:

... arrest and prosecution of Philippine National Police personnel, through the conduct of counter-intelligence operations, who are engaged in unlawful activities such as, but not limited to, illegal arrest, illegal detention ( . . ) or case fixing recycling of confiscated drugs, or acting as protectors, coddlers, and financiers of drug personalities. (Calisco et al. 2017)

In alignment with this strategy, the government has significantly increased the public budget for public order, safety, and domestic security, but instead of distributing those resources among the different agencies of the criminal justice system, those resources have been overwhelmingly directed at strengthening the police force. Therefore, the government's approach has clearly focused on police monopolising the leadership in an area that has become central for the public. However, police leadership promotes unfiltered violence from the state as a response to crime, which is even more problematic due to the alleged corruption pervading the police and other governmental agencies.

Nevertheless, a recent shift policy has ceased the involvement of the Philippine National Police in operations against illegal drugs and has halted Project Double Barrel (Tupas 2017). Statements made by an Associate Justice of the Supreme Court that have qualified the police procedures as a violation of the Anti-Torture Law may be signalling the recovery of the courts' leadership (Torres-Tupas 2017).

\section{Conclusions}

A comparative analysis of the loss of leadership of criminal judges in the Global South identified common social and political factors that result in dangerous punitive trends. The combination of economic policies and the politicisation of crime have increased and maintained social inequality. Judicial systems are required to handle an ever-increasing fear of crime fuelled by the media and politicians. In some aspects, this phenomenon is similar to the rise of penal punitivism in the Global North; the level of inequality and the inability of judicial bureaucracies to address crime have enabled a more dangerous type of popular punitivism. In societies with an authoritarian legacy, the control of police and ensuring the due process must be a priority. Measures to increase the efficiency of courts, based on the neoliberal paradigm that actually curtail the court's ability to control police, are problematic and may promote police impunity.

The case of the Philippines shows the extreme results of the complete loss of leadership of criminal judges, acting as a warning sign for other societies in the Global South of the consequences of eroding the courts' role in justice and social order. An example of this danger are the recent open statements by Indonesia's President Joko Widodo who, similar to Duterte's policies, has ordered the police to shoot drug traffickers who resist arrest in the latest effort to eradicate drug use in the country (Agence France-Presse 2017). These situations highlight the importance of building a strong judiciary that has the political and moral leadership to face popular punitive strategies that, in societies of the Global South with authoritarian legacies, can degenerate into unbridled state violence.

Argentina has demonstrated that managerial reforms can also weaken the courts' leadership by reducing their ability to control the police. Foreign institutions that seek to improve courts' efficiency, such as plea bargaining, have had severe impacts in a heavily economically and socially polarised society with an authoritarian police force.

The comparative work between societies in the Global South should allow the identification of common problems that emerge from similar economic and political conditions. The solutions have historically been imported from the Global North. Given the failures of these reforms, we should look to our equals and open a dialogue to understand what can be learned from each others' experiences. 
Acknowledgments: I am grateful to the editors for the invitation to contribute to this special issue. I would also like to thank the anonymous reviewers for their insightful comments.

Conflicts of Interest: The author declares no conflict of interest.

\section{References}

Agence France-Presse. 2017. Shoot Drug Traffickers if They Resist Arrest-Indonesia's Widodo. Available online: http: / / newsinfo.inquirer.net/916347/shoot-drug-traffickers-if-they-resist-arrest-indonesias-widodo\# ixzz4sKtMdHW4 (accessed on 23 July 2017).

Auyero, Javier, and Katherine Sobering. 2017. Violence, the State, and the Poor: A View from the South. Sociological Forum 32: 1018-31. [CrossRef]

Barrera, Dan Jerome. 2017. Drug War Stories and the Philippine President. Asian Criminology 12: 341-59. [CrossRef]

Bastard, Benoit, David Delvaux, Christian Mouhanna, and Frédéric Schoenaers. 2016. Justice ou Precipitation: L'accélération du Temps Dans les Tribunaux. Rennes: PUR.

Binder, Alberto. 1997. Política Criminal: De la Formulación a la Praxis. Buenos Aires: Ad Hoc.

Binder, Alberto. 2002. Los oficios del jurista: La fragmentación de la profesión jurídica y la uniformidad de la carrera judicial. Sistemas Judiciales 1: 34-53.

Brants, Chrisje, and Stijn Franken. 2009. The protection of fundamental human rights in criminal process, General report. Utrecht Law Review 5: 7-65. [CrossRef]

Brown, Wendy. 2003. Neo-liberalism and the End of Liberal Democracy. Theory and Event 7: 37-59. [CrossRef]

Calisco, Rose, Tristan Canare, and Emmanuel Garcia. 2017. Shaping the Public Perception toward Local Authorities: The Role of Perceived Social, Economic, and Political Insecurities. RSN-PCC Working Paper, 17-004. Available online: https:/ / ssrn.com/abstract=2941994 (accessed on 10 December 2017).

Carranza, Elías. 1996. Estado actual de la prisión preventiva en América Latina y comparación con los países de Europa. Jueces Para la Democracia 26: 81-88.

Carrington, Kerry, and Russell Hogg. 2017. Deconstructing Criminology's Origin Stories. Asian Criminology 12: 181-97. [CrossRef]

Carrington, Kerry, Russell Hogg, and Máximo Sozzo. 2015. Southern Criminology. British Journal of Criminology 56: 1-20. [CrossRef]

Cavadino, Michale, and James Dignan. 2006. Penal Systems: A Comparative Approach. London: SAGE.

Ciencia Jr., Alejandro. 2012. From Judicialization to Politicization of the Judiciary: The Philippine Case. In The Judicialization of Politics in Asia. Edited by Björn Dressel. Abingdon: Routledge, pp. 117-38.

Ciocchini, Pablo. 2014. Campaigning to Eradicate Court Delay: Power Shifts and New Governance in Criminal Justice. Crime, Law and Social Change 61: 61-79. [CrossRef]

Ciocchini, Pablo, and Stefanie Khoury. 2017. A Gramscian Approach to Studying the Judicial Decision-Making Process. Critical Criminology, 1-16. [CrossRef]

Comaroff, Jean, and John Comaroff. 2014. Law and Disorder in the Postcolony. Chicago: University of Chicago Press.

Commaille, Jacques. 1998. La régulation des temporalités juridiques par le social et le politique. In Temps et Droit. Le Droit a-t-il Pour Vocation de Durer? Edited by François Ost and Mark Van Hoecke. Bruxelles: Bruylant, pp. 317-39.

Corrales, Nestor. 2016. Duterte's New Drug list: 40 Judges, '1 page' for Chinese Suspects. Available online: http://newsinfo.inquirer.net/817675/dutertes-new-drug-list-40-judges-1-page-forchinese-suspects\#ixzz4sJjzalDo (accessed on 21 September 2016).

Curato, Nicole. 2016. Politics of Anxiety, Politics of Hope: Penal Populism and Duterte's Rise to Power. Journal of Current Southeast Asian Affairs 35: 91-109.

Dados, Nour, and Raewyn Connell. 2012. The Global South. Contexts 11: 12-13. [CrossRef]

Damaska, Mirjan. 1986. The Faces of Justice and State Authority: A Comparative Approach to the Legal Process. New Haven: Yale University Press.

Dezalay, Yves, and Bryant Garth. 2011. Lawyers and the Rule of Law in an Era of Globalization. Abingdon: Routledge.

Dressel, Björn. 2012. The judicialization of politics in Asia: Towards a framework of analysis. In The Judicialization of Politics in Asia. Edited by B. Dressel. Abingdon: Routledge, pp. 1-14.

Duce, Mauricio. 2009. Reforma de la justicia penal en América Latina: Una perspectiva panorámica y comparada, examinando su desarrollo, contenidos y desafíos. UDP Public Policy Series-Working Papers 3: 1-39. 
Duce, Mauricio, and Rogelio Pérez Perdomo. 2001. Seguridad, ciudadanía y reforma de la justicia penal en América Latina. Boletín Mexicano de Derecho Comparado XXXIV: 755-87.

Duce, Mauricio, Alejandra Mera, and Cristián Riego. 2002. La capacitación interinstitucional en la reforma a la justicia criminal en Chile. Sistemas Judiciales 1: 55-72.

Eisenstein, James, Roy Flemming, and Peter Nardulli. 1999. The Countours of Justice: Communities and Their Courts. Lanham: University Press of America.

Eser, Albin. 1996. The Acceleration of Criminal Proceedings and the Rights of the Accused: Comparative Observations as to the Reform of Criminal Procedure in Europe. Maastricht Journal of European and Comparative Law 3: 341-70. [CrossRef]

Fajnzylber, Pablo, Daniel Lederman, and Norman Loayza. 2002. Inequality and Violent Crime. Journal of Law and Economics 45: 1-39. [CrossRef]

Fondevila, Gustavo, Máximo Langer, Marcelo Bergman, Carlos Vialta, and Alberto Mejía. 2016. ¿Cómo se Juzga en el Estado de México? Una Radiografía de la Operación del Sistema de Justicia Penal Acusatorio. México City: CIDE.

Foucault, Michel. 2008. The Birth of Biopolitics: Lectures at the Collège De France, 1978-1979. Basingstoke: Palgrave Macmillan.

Garapon, Antoine, and Ioannis Papadopoulos. 2003. Juger en Amérique et en France. Paris: Odile Jacob.

Garland, David. 2001. The Culture of Control: Crime and Social Order in Contemporary Society. Oxford: OUP.

Gatmaytan, Dante. 2012. Politicisation and Judicial Accountability in the Philippines. Philippine Law Journal 8: 21-50.

Gutierrez, Mariano Ezequiel Kostenwein. 2017. Coyuntura y frentes de tormenta. La política criminal de la Provincia de Buenos Aires 1996-2014. In Sociología de la Justicia Penal. Edited by Ezequie Kostenwein. Buenos Aires: Ediar, pp. 261-303.

Harvey, David. 2005. A Brief History of Neo-Liberalism. Oxford: Oxford University Press.

Hazán, Luciano, and Cristián Riego. 2007. La oralidad en las etapas previas al juicio: La experiencia de Mar del Plata. In Reformas Procesales en América Latina: Resultados del Proyecto de Seguimiento, IV Etapa. Edited by Cristián Riego. Santiago: CEJA, pp. 255-94.

Gretchen Helmke, and Julio Ríos-Figueroa, eds. 2011. Courts in Latin America. Cambridge: Cambridge University Press.

Hinton, Mercedes, and Tim Newburn. 2008. Policing Developing Democracies. Abingdon: Routledge.

Hirschl, Ran. 2006. The New Constitution and the Judicialization of Pure Politics Worldwide. Fordham Law Review 75: 721-53. Available online: http:/ /ir.lawnet.fordham.edu/flr/vol75/iss2/14 (accessed on 10 December 2017).

Hollender, Rebecca. 2015. Post-Growth in the Global South: The Emergence of Alternatives to Development in Latin America. Socialism and Democracy 29: 73-101. [CrossRef]

Holmes, Oliver. 2016. Philippines President Rodrigo Duterte Says He Personally Killed Criminals. The Guardian. December 14. Available online: https: / www.theguardian.com/world/2016/dec/14/philippines-presidentrodrigo-duterte-personally-killed-criminals (accessed on 10 December 2017).

Human Rights Watch. 2017. “License to Kill” Philippine Police Killings in Duterte's “War on Drugs”. Available online: https:/ / www.hrw.org/sites /default/files/report_pdf/philippines0317_insert_lowres_spreads_1. pdf (accessed on 10 December 2017).

Hyden, Goran, Julius Court, and Ken Mease. 2003. The Bureaucracy and Governance in 16 Developing Countries. World Governance Survey, Discussion Paper 7. Available online: https://www.odi.org/sites/odi.org.uk/ files/odi-assets/publications-opinion-files/4104.pdf (accessed on 10 December 2017).

Indermaur, David, and Lynne Roberts. 2009. Confidence in the Criminal Justice System. Canberra: Australian Institute of Criminology.

Kapiszewski, Diana, and Matthew Taylor. 2008. Doing Courts Justice? Studying Judicial Politics in Latin America. Perspectives on Politics 6: 741-67. [CrossRef]

Kessler, Gabriel. 2016. Controversias Sobre la Desigualdad: Argentina 2003-2013. Buenos Aires: Fondo de Cultura Económica.

Kohler-Hausmann, Issa. 2014. Managerial Justice and Mass Misdemeanors. Faculty Scholarship Series, Paper 4913. Available online: http:/ / digitalcommons.law.yale.edu/fss_papers/4913 (accessed on 10 December 2017).

Kostenwein, Ezequiel. 2015. Prisión preventiva: Entre los medios de comunicación y las autoridades políticas. Revista Direito e Práxis 6: 54-79. [CrossRef] 
Kreuzer, Peter. 2016. If They Resist, Kill Them All: Police Vigilantism in the Philippines. PRIF Reports 142, Frankfurt Am Main. Available online: https://www.hsfk.de/fileadmin/HSFK/hsfk_publikationen/prif142. pdf (accessed on 10 December 2017).

Langer, Máximo. 2007. Revolution in Latin American Criminal Procedure: Diffusion of Legal Ideas from the Periphery. American Journal of Comparative Law 55: 617-76. [CrossRef]

Levitt, Steven. 2004. Understanding Why Crime Fell in the 1990s: Four Factors that Explain the Decline and Six that Do Not. Journal of Economic Perspectives 18: 163-90. [CrossRef]

Maier, Julio. 1993. Democracia y administración de justicia penal en Iberoamérica: Los proyectos para la reforma del sistema penal. In Reformas Procesales en América Latina: La Oralidad en los Procesos. Santiago: Corporación de Promoción Universitaria.

Mattei, Ugo. 2003. A Theory of Imperial Law: A Study on U.S. Hegemony and the Latin Resistance. Indiana Journal of Global Legal Studies 10: 383-448. [CrossRef]

Medina, Mikaela. 2017. Extrajudicial Punishments to Combat the Philippine Drug War: Problem or Solution? Loyola University of Chicago International Law Review 14: 155-74.

Morgan, Rod. 2009. The Quiet Revolution: The Rise and Rise of Out-of-Court Summary Justice. Criminal Justice Matters 75: 5-6. [CrossRef]

Müller, Markus-Michael. 2012. The rise of the penal state in Latin America. Contemporary Justice Review: Issues in Criminal, Social, and Restorative Justice 15: 57-76. [CrossRef]

Nelken, David. 2011. Comparative Criminal Justice and Globalization. Farnham: Ashgate.

Oyanedel, Juan Carlos J. 2016. Confianza en la justicia y la policía en América Latina: Análisis de los efectos de las reformas procesales penales (1995-2013). Reforma y Democracia 64: 141-64.

Pasará, Luis. 2015. Reforma Procesal y Reforma Judicial. Available online: http:/ / perso.unifr.ch/derechopenal/ assets / files/temas/t_20080528_08.pdf (accessed on 10 December 2017).

Patalinghug, Epictetus. 2011. Crime rates and labor market opportunities in the Philippines: 1970-2008. Economics Letters 113: 160-64. [CrossRef]

Plant, Raymond. 2010. The Neo-Liberal State. Oxford: Oxford University Press.

Popova, Maria. 2012. Politicized Justice in Emerging Democracies: A Study of Courts in Russia and Ukraine. Cambridge: Cambridge University Press.

Pratt, John. 2007. Penal Populism. London: Routledge.

Punay, Edu. 2017a. Speedy justice set to roll out nationwide. The Philippine Star. Available online: http: / / www.philstar.com/headlines/2017/05/08/1697868/speedy-justice-set-roll-out-nationwide (accessed on 10 December 2017).

Punay, Edu. 2017b. Judicial Reforms to Fight Impunity in HR Violation. The Philippine Star, February 24. Available online: http:/ / www.philstar.com/headlines/2017/02/24/1675290/judicial-reforms-fight-impunity-hrviolation (accessed on 10 December 2017).

Ramos, Marlon. 2017. Days of Disquiet in Judiciary under Duterte. Available online: http:/ /newsinfo.inquirer. net/916532/days-of-disquiet-in-judiciary-under-duterte (accessed on 24 July 2017).

Rauhala, Emily. 2016. Before Duterte Was the Philippines' President, He Was 'the Death Squad Mayor'. The Washington Post, September 28. Available online: https:/ /www.washingtonpost.com/world/asia_pacific/ before-duterte-was-the-philippines-president-he-wasthe-death-squad-mayor/2016/09/28/f1d1ccc4800b-11e6-ad0e-ab0d12c779b1_story.html (accessed on 10 December 2017).

REDEX. 2010. Presentación red de capacitadores en reforma judicial Redex Argentina. In Primer Encuentro Nacional Redex Argentina. Córdoba: Advocatus, pp. 11-14.

Reiner, Robert. 2007. Law and Order: An Honest Citizen's Guide to Crime and Control. Cambridge: Polity Press.

Romero, Alexis. 2017. Duterte: Killing Criminals Not a Crime against Humanity. Philstar.com, March 2. Available online: http:/ / www.philstar.com/headlines/2017/03/02/1677427/duterte-killing-criminals-not-crimeagainst-humanity (accessed on 10 December 2017).

Santos, Boaventura de Sousa. 2002. Toward a New Legal Common Sense: Law, Globalization and Emancipation, 2nd ed. London: Butterworths/LexisNexis.

Santos, Boaventura de Sousa. 2016. Epistemologies of the South and the Future. From the European South: A Transdisciplinary Journal of Postcolonial Humanities 1: 17-29.

Shapiro, Martin. 1981. Courts: A Comparative and Political Analysis. Chicago: University of Chicago Press. 
Simon, Jonathan. 2007. Governing through Crime: How the War on Crime Transformed American Democracy and Created a Culture of Fear. Oxford: Oxford University Press.

Stürmer, Martin. 2010. Let the Good Times Roll? Raising Tax Revenues from the Extractive Sector in Sub-Saharan Africa during the Commodity Price Boom. Bonn: German Development Institute.

Svampa, Maristella. 2013. "Consenso de los Commodities" y lenguajes de valoración en América Latina. Nueva Sociedad, 244. Available online: http:/ / nuso.org/articulo/consenso-de-los-commodities-y-lenguajes-devaloracion-en-america-latina/ (accessed on 10 December 2017).

Swanson, Kate. 2013. Zero Tolerance in Latin America: Punitive Paradox in Urban Policy Mobilities. Urban Geography 7: 972-88. [CrossRef]

Tadiar, Alfredo. 1980. Some Role/Functions in the Administration of Criminal Justice. Philippine Law Journal 55: 32-50.

Tate, Neal. 1987. Judicial Institutions in Cross-National Perspective: Toward Integrating Courts into the Comparative Study of Politics. In Comparative Judicial Systems: Challenging Frontiers in Conceptual and Empirical Analysis. Edited by John R. Schmidhauser. London: Butterworths, pp. 7-33.

Tate, Neal. 1994. The Judicialization of Politics in the Philippines and Southeast Asia. International Political Science Review 15: 187-97. [CrossRef]

Taub, Amanda. 2016. How Countries Like Philippines Fall into Vigilante Violence. The New York Times. September 11. Available online: https:/ / nyti.ms /2cF7kN6 (accessed on 10 December 2017).

Timberman, David. 2016. Elite Democracy Disrupted? Journal of Democracy 27: 135-44. [CrossRef]

Torres-Tupas, Tech. 2014. Sereno Seeks for More Budget for Judiciary Reforms. Available online: http:/ / newsinfo. inquirer.net/640461/sereno-seeks-more-budget-for-judiciary-reforms (accessed on 10 December 2017).

Torres-Tupas, Tech. 2017. Leonen: Forcing Drug Suspects to Open Door to Cops Violates Anti-Torture Law. Available online: https:/ / newsinfo.inquirer.net/946643/forcing-drug-suspects-to-open-door-to-copsviolates-anti-torture-law-says-leonen (accessed on 10 December 2017).

Tupas, Emmanuel. 2017. PNP ends Tokhang, Double Barrel. The Philippine Star. October 13. Available online: http:/ / www.philstar.com/headlines/2017/10/13/1748255/pnp-ends-tokhang-double-barrel (accessed on 10 December 2017).

Van De Kerchove, Michael. 1998. Accélération de la justice pénale et traitement en "temps réel”. In Temps et Droit. Le Droit a-t-il Pour Vocation de Durer? Edited by François Ost and Mark Van Hoecke. Bruxelles: Bruylant, pp. 367-84.

Vogler, Richard. 2005. A World View of Criminal Justice. Aldershot: Ashgate.

Wacquant, Loïc. 2009. Punishing the Poor: The Neoliberal Government of Social Insecurity. Durham: Duke University Press.

Werner, Matías. 2017. Jueces garantistas o desidia judicial? Diario Judicial. April 10. Available online: http: / / www.diariojudicial.com/nota/77843 (accessed on 10 December 2017).

Whyte, David. 2009. Naked Labour: Putting Agamben to Work. Australian Feminist Law Journal 31: 57-76. [CrossRef]

Widner, Jennifer. 2000. The Courts as a Restraint: The Experience of Tanzania, Uganda and Botswana. In Investment and Risk in Africa. Studies on the African economies. Edited by Paul Collier and Catherine Pattillo. London: Palgrave Macmillan.

Jiunn-Rong Yeh, and Wen-Chen Chang, eds. 2015. Asian Courts in Context. Cambridge: Cambridge University Press.

Young, Jock. 2001. Identity, community and social exclusion. In Crime, Disorder, and Community Safety: A New Agenda? Edited by Roger Matthews and John Pitts. London: Routledge, pp. 26-53.

(c) 2017 by the author. Licensee MDPI, Basel, Switzerland. This article is an open access article distributed under the terms and conditions of the Creative Commons Attribution (CC BY) license (http:/ / creativecommons.org/licenses/by/4.0/). 